\title{
Creatures Bound For Glory: Biotechnological Enhancement and Visions of Human Flourishing
}

\section{Authors}

Michael Burdett

Department of Theology and Religious Studies

University of Nottingham

University Park

Nottingham, NG7 2RD

United Kingdom

Victoria Lorrimar

Trinity College Queensland

60 Bayliss $\mathrm{St}$

Auchenflower QLD 4066

AUSTRALIA

\begin{abstract}
The human enhancement debate is fundamentally based on divergent ideals of human flourishing. Using the complementary, though often contrasting, foci of creaturehood and deification as fundamental to the good life, we examine these visions of human flourishing inherent in transhumanist, secular humanist, and critical posthumanist positions on human enhancement. We argue that the theological anthropologies that respond to human enhancement and these other ideologies tend to emphasise either creaturehood or deification to the neglect or detriment of the other. We propose in response that understanding humans as creatures bound for glory integrates both dimensions of the human being into the one grand vision of flourishing God has for humanity.
\end{abstract}

\section{Key words}

Human enhancement, flourishing, transhumanism, secular humanism, critical posthumanism, human malleability 
What is the good life? All responses to biotechnological enhancement are, often implicitly, guided by an underlying picture of human flourishing. Utopian visions line up at opposing ends of the technological spectrum, from idyllic pre-industrial sustainable communities to high tech societies in which we have modified our own biology in astonishing fashion.

Divergent ideals for human prosperity compete with each other in the arena of technological innovation, particularly when it comes to the prospective technological enhancement of human physiology and capabilities. The stakes seem especially high when we are dealing with potential alterations to 'human nature'. Elaine Graham contends that emerging cybernetic, digital and genetic technologies 'call into question the deepest assumptions underlying our notions of normative and exemplary humanity'. ${ }^{1}$ Most often, enquiries into these underlying assumptions have considered the status of human nature (i.e. determined or plastic), ${ }^{2}$ but not the more abstract questions concerning human flourishing. Scholarship on enhancement issues has largely ignored questions concerning flourishing and the meaning of life, suggests Anders Sandberg, 'perhaps because of the reluctance of postmodern academia to engage with "great stories" that provide an overarching explanation of life or give universal moral principles'. ${ }^{3}$

From a religious standpoint, defining human flourishing involves the notions of creaturehood and deification. Human beings are a particular kind of creature created by God such that living according to this nature, and its associated embedded and presupposed principles, means human beings will flourish. The notion of creaturehood invokes particular characteristics and values that are often shared with other creatures: dependency on God as ultimate source and aim, dependency on one another and the entire 'fellowship of creation' and that the very structure of creaturely life is ordered to its own good and praise of God. ${ }^{4}$ In human enhancement circles creaturehood serves a conserving function where human beings remember the goodness of their present life that coheres with their present natures. Indeed, theological engagements with human enhancement that favour creaturehood often implicitly focus on how our present natures are, on the whole, capable of flourishing now, ${ }^{5}$ and that part of this flourishing consists in

\footnotetext{
${ }^{1}$ Elaine Graham, 'Bioethics after Posthumanism: Natural Law, Communicative Action and the Problem of Self-Design', Ecotheology 9, no. 2 (2004), p. 179.

${ }^{2}$ E.g. see Gerald McKenny, 'Biotechnology and the Normative Significance of Human Nature: A Contribution from Theological Anthropology', Studies in Christian Ethics 26:1 (2013), pp. 22-23

${ }^{3}$ Anders Sandberg, 'Transhumanism and the Meaning of Life', in Religion and Transhumanism: The Unknown Future of Human Enhancement, ed. Calvin Mercer and Tracy Trothen (Santa Barbara, CA: Praeger Publishers, 2015), p. 8.

${ }^{4}$ For an excellent treatment of creaturehood and goodness see John Webster, "Love Is Also a Lover of Life": Creatio Ex Nihilo and Creaturely Goodness', Modern Theology 29, no. 2 (2013).

${ }^{5}$ On the whole because while it might be possible to flourish with our present nature the issue of sin's impact on that nature looms large and certainly influences the very possibility of that flourishing. Of course all Christians would believe that, this side of the Fall, flourishing is only possible with the aid of divine grace even when one recognises that one's created nature is entirely an act of grace as well.
} 
acknowledging the goodness of creaturely life and living within that thankfulness - receiving all as pure gift.

And yet human beings are a particular kind of creature like no other theologically. Human beings enjoy adoption in Christ to share and participate in transformation and elevation to intimate life with God. In other words, human beings are also deified by divine grace and share in God's image and likeness unlike any other creature. Human beings imaginatively create, reflect, make judgements and act on their present circumstances and on the world around them. It is precisely these transcendent dimensions of human being, that humans are said to be exocentric, open to the world and in creative relation to it, ${ }^{6}$ that also typifies and defines them. In the context of human enhancement discussions, deification can represent this exceeding dimension of creativity and growth. Christians that focus on this aspect of human being emphasise our role as co-creators with God-we flourish when we exercise this gifted power. Our flourishing is not like that of other creatures, precisely because the transformation of our sinful natures and subsequent participation in God's own life impact that flourishing such that we cannot understand human glory aside from the super-gratuity offered by our deification in Christ. We were created to ascend and participate, and our flourishing takes its cue from the beatific vision that marks this creative intention of God. ${ }^{7}$

But before turning to theological accounts of human flourishing in the context of human enhancement we need to first attend to how other perspectives treat it.

\section{Transhumanism, human flourishing and future transformation}

Transhumanism is an entirely future-oriented ideology that advocates for human technological enhancement. The term transhumanism indicates an unhappiness with the present state of the human being and instead focuses on how the human being is or ought to be transformed entirely now and in the future. Indeed, it is the nascent advocacy of such transformation by enhancement technologies to a 'trans' or 'post' human state that is its core identifying feature today. Yet embedded within this belief to transform the human being is an argument that one ought to transform oneself and that one ought to do so with enhancement technologies. In other words, underlying the core principle of transhumanism is an operative vision of human flourishing.

\footnotetext{
${ }^{6}$ See Wolfhart Pannenberg, Anthropology in Theological Perspective, trans. Matthew J. O'Connell (London: T \& T Clark, 1985), pp. 43-79.

${ }^{7}$ For as Irenaeus has said: 'Now it was necessary that man should in the first instance be created; and having been created, should receive growth; and having received growth, should be strengthened; and having been strengthened, should abound; and having abounded, should recover [from the disease of sin]; and having recovered, should be glorified; and being glorified, should see his Lord. For God is He who is yet to be seen, and the beholding of God is productive of immortality, but immortality renders one nigh unto God.' Against Heresies IV.38.3 (Ante-Nicene Fathers 1:522).
} 
There is assumed within its tenets 'better modes of being' ${ }^{8}$, practices and 'ways of life' ${ }^{9}$ that are hitherto inaccessible or impossible to human beings in their present condition. What is more, transhumanist conceptions of human flourishing become clear when focusing on these visions of future transformation and how they relate to present abilities, capacities or modes of being. As will become apparent, transhumanist accounts of flourishing reveal that present human capacities are deficient in allowing humanity to flourish and, hence, only a future posthuman state will achieve this.

Nick Bostrom identifies three areas of present human life that ought to be transcended and, hence, reveal what is needed to flourish. ${ }^{10}$ First, our present lifespans need to be seriously increased. Bostrom notes that many social scientific surveys that ask people today explicitly whether they would like to live longer actually show a meagre interest in expanding our current lifespans. ${ }^{11}$ Bostrom notes that this lack of interest amongst those surveyed might be due to a mistaken impression that our quality of life is reduced the more we extend life because of ageing and loss of function and ability. ${ }^{12}$ But certainly, Bostrom claims, its uncontested that expanding a healthy life hundreds, if not thousands, of years is both desired and good.

Transhumanists devote significant resources to extending our lifespans. Aubrey de Grey is a longevity specialist and transhumanist who studies the Hayflick Limit, the biological basis of cellular decay and death. De Grey researches the biological basis for 'natural death' so that we might reverse it and live longer. ${ }^{13}$ Ray Kurzweil is another transhumanist who famously ingests hundreds of pills a day to reprogramme his body chemistry for longevity - he is actively seeking to 'live forever'. ${ }^{14}$ But certain transhumanists that advocate for 'mind uploading' recognise that the biological basis of our existence is likely a dead end if we want to live much longer. They seek instead to virtually copy themselves through reverse engineering the entire brain or nervous system to be uploaded into silicon-based hardware. The transhumanist advocacy to seriously increase human lifespans indicates they think we need to live longer lives to be satisfied and to flourish.

Bostrom identifies cognition as the second area in need of transformation to live well. He says 'Who wouldn't want to remember names and faces better, to be able more quickly to grasp difficult abstract ideas, and to be able to "see connections" better? Who would seriously object to

\footnotetext{
${ }^{8}$ Nick Bostrom, 'Why I Want to be a Posthuman When I Grow Up', in The Transhumanist Reader, ed. Max More and Natasha Vita-More (Oxford: Blackwells, 2013), pp. 31-32.

${ }^{9}$ ibid., pp. 43-45.

${ }^{10}$ ibid., pp. 35-38.

11 ibid., p. 33.

12 ibid., p. 34.

${ }^{13}$ Aubrey D. N. J. de Grey and Michael Rae, Ending Aging: The Rejuvenation Breakthroughs That Could Reverse Human Aging in Our Lifetime (New York: St. Martin's Press, 2007).

${ }^{14}$ Ray Kurzweil and Terry Grossman, Fantastic Voyage: Live Long Enough to Live Forever (Emmaus: Rodale, 2004).
} 
being able to appreciate music at a deeper level? The value of optimal cognitive functioning is so obvious that to elaborate the point may be unnecessary. ${ }^{15}$ Given how central our internal, mental life is to how we experience the world and who we are, it is unsurprising that transhumanists advocate so strongly for the enhancement of these cognitive capacities. They certainly would seem to impact happiness and well-being more directly than other enhancement candidates.

Transhumanists seek all kinds of cognitive enhancing measures. In the short-term they might send small electrical currents through certain parts of the brain, sometimes called brain hacking, to increase 'flow states', better attention and quicker learning of things like language. ${ }^{16}$ They might experiment with cognitive enhancing drugs like Ritalin, Modafinil and Adderall—much like many university students do today to increase attention span and to stay awake longer. But the long-term cognitive enhancing measures include things like brain-machine interfaces, so that computer memory could be directly accessed by the brain, or even melding with AI and computers so that human beings could reap the processing power and pattern recognition of these technologies. For the transhumanist, our current cognitive abilities are not good enough for us to be happy and, hence, require enhancement.

Finally, Bostrom argues that transhumanism seeks to enhance our emotional lives. While measuring emotional states and their enhancement is fraught with difficulty, it is clear to Bostrom and others that we cannot flourish without good affective states and that there are serious issues with what we have been endowed presently. Our anger and hatred does not only affect our personal well-being, but, if we act out of that anger or hatred, we could also harm others and reduce their flourishing. It is hard not to envision Huxley's Brave New World here with the excessive use of the drug soma to counteract all the bad feelings in society and give everyone the 'warm fuzzies'. But, Bostrom might say, it was the imprecise use of soma and its use to pacify people in Brave New World that differs from the transhumanist proposal. We would do better to look to highly trained yogis and monks as our template, for they have not only learned to tame and direct the passions but also to enjoy life and experience that affective component of inner peace. Already we are seeing transhumanists advocate for the use of oxytocin and psilocybin to create feelings of comfort, connection with others and heightened internal states of pleasure and joy. Again, our emotions are too rudimentary, unsophisticated and troublesome to make us happy and, thus, we need to enhance them.

As one can discern, transhumanism is about dissatisfaction with our current abilities and the way they are insufficient for our flourishing and happiness. What they propose in response is a

\footnotetext{
${ }^{15}$ Bostrom, 'Posthuman When I Grow Up', p. 35.

${ }^{16}$ Maria Konnikova, 'Hacking the Brain: How We Might Make Ourselves Smarter in the Future', The Atlantic (2015), accessed March 27, 2018, https://www.theatlantic.com/magazine/archive/2015/06/brainhacking/392084/.
} 
complete overhaul of the human being so that it might live longer, enjoy greater cognitive prowess and experience more robust and pleasurable inner states.

\section{Secular humanist approaches to enhancement}

Often termed 'bioconservatives', a group of prominent thinkers that largely identify as 'secular humanist', have cautioned against human technological enhancement. The President's Council on Bioethics, appointed by U.S. President George W. Bush to provide the administration with philosophical guidance on bioethical issues from 2001-2009, broadly adopted this approach. The work of council members Leon Kass, Michael Sandel and Francis Fukuyama are representative, and these individuals are generally positioned as counterpoints to the transhumanists treated in the last section.

Keenly aware of the importance of human flourishing in the enhancement debate, Kass, the Council chair, envisions a public bioethics that begins 'by reflecting upon the highest human goods and understanding the latest technological advances in this light'. ${ }^{17} \mathrm{He}$ examines the ends, the means, and the overarching narrative of meaning in which the drive to master one's own nature is situated. ${ }^{18}$ Kass identifies a problem when the means to a particular end becomes unintelligible and disconnected from the human significance that usually accompanies the natural means to such an end (e.g. the use of pharmaceutical mood enhancers to achieve what is usually stimulated by natural human experiences such as encountering a loved one). ${ }^{19}$

According to Kass, technological enhancement of human capacities disrupt, dilute and distort 'the deep structure of unimpeded, for-itself, human being-at-work-in-the-world' which constitutes human flourishing. ${ }^{20}$ Flourishing is concerned with 'exercising one's human powers well and without great impediment'. ${ }^{21}$ Finitude is not disadvantageous; it conditions the best things in human life: 'engagement, seriousness, a taste for beauty, the possibility of virtue, the ties born of procreation, the quest for meaning'. ${ }^{22}$ Enhancement is not only unnecessary but often undesirable, for 'genuine human flourishing is rooted in aspirations born of the kinds of deficiencies that come from having limited and imperfect bodies'. ${ }^{23}$

\footnotetext{
${ }^{17}$ Leon Kass, 'Reflections on Public Bioethics: A View from the Trenches', Kennedy Institute of Ethics Journal 15, no. 3 (2005), p. 246.

${ }^{18}$ Leon Kass, 'Ageless Bodies, Happy Souls: Biotechnology and the Pursuit of Perfection', The New Atlantis 1 (2003), p. 167.

19 ibid., p. 22.

${ }^{20}$ ibid., p. 24.

21 ibid., p. 23, emphasis original.

22 ibid., p. 25. C.f. Leon Kass, 'L'Chaim and its Limits: Why Not Immortality?', First Things 113 (2001), p. 17-24.

${ }^{23}$ Kass, 'Ageless Bodies, Happy Souls', p. 27.
} 
Secular humanists tend to object to enhancement on the basis that it undermines the heterogeneity of society, and therefore hinders 'genuine freedom, individuality, and greatness'.24 Pointing to Aldous Huxley's Brave New World as an example, Kass argues that 'biotechnical powers used to produce contentment in accordance with democratic tastes threaten the character of human striving and diminish the possibility of human excellence' ${ }^{25}$ Similarly, Fukuyama links human flourishing with the preservation of universal human rights. He celebrates certain human qualities - emotion, reason, intelligence, creativity, and morality - the protection and practice of which promote human flourishing, and considers technological enhancement of human characteristics to pose a threat to these qualities. ${ }^{26}$

Furthermore, Fukuyama argues liberal democracies themselves would be entirely undermined if human enhancements were widely introduced because human equality of nature, the basis for liberal democracy, would no longer be fixed in society. ${ }^{27}$ Arguing that human dignity, which occupies a central place in his vision of human flourishing, is grounded in a 'complex diversity of natural ends and purposes', Fukuyama rejects biotechnology for its tendency to reduce these complex ends into simple utilitarian ones - autonomy, pain, pleasure, etc. ${ }^{28}$ Sandel takes a similar line, critiquing both the means and the ends of technological enhancement that 'threatens our humanity by eroding human agency. Its ultimate expression is a wholly mechanistic understanding of human action at odds with human freedom and moral responsibility.'29

Sandel summarises the dangers presented by enhancement:

... changing our nature to fit the world, rather than the other way around, is actually the deepest form of disempowerment. It distracts us from reflecting critically on the world, and deadens the impulse to social and political improvement. ${ }^{30}$

Gerald McKenny offers a valuable analysis of the various ways in which natural goods are grounded in human nature for these secular humanist thinkers. ${ }^{31}$ Yet underlying conceptions of human nature and its normative significance are not the only determinant for responses to biotechnological enhancement; visions of the good life and what constitutes human flourishing also operate.

${ }^{24}$ ibid., p. 16.

25 ibid., p. 17.

${ }^{26}$ Francis Fukuyama, Our Posthuman Future: Consequences of the Biotechnology Revolution (New York, NY: Farrar, Straus and Giroux, 2002), p. 172.

${ }^{27}$ ibid., p. 175. An excellent critique of this view is offered by McKenny, 'Biotechnology', pp. 22-23.

${ }^{28}$ Fukuyama, Our Posthuman Future, p. 172.

${ }^{29}$ See Michael Sandel, The Case Against Perfection: Ethics in the Age of Genetic Engineering (Cambridge, MA: Belknap Press, 2007), pp. 24-26.

${ }^{30}$ ibid., p. 97.

${ }^{31}$ McKenny, 'Biotechnology', pp. 21-23. 


\section{Human flourishing in transhumanism vs. secular humanism}

To understand the various responses to human enhancement described above, it is worth exploring further the visions of human flourishing that inform them. Though transhumanists and secular humanists overlap in some respects in their idea of the good life, they are radically opposed when it comes to the role that technology might play in bringing such visions to fruition. ${ }^{32}$

Erik Parens contends that both secular humanists and transhumanists ground their respective arguments for and against enhancement on the basis of authenticity. ${ }^{33}$ Yet they interpret the moral ideal of authenticity quite differently. Parens applies to the enhancement debates Charles Taylor's account of the divergent ways in which the critics and proponents of modernity appeal to authenticity. Critics perceive of such technologies as a threat to achieving authenticity, while proponents see them as assisting us to become more authentic — with the understanding that 'we are authentic when we exhibit or are in possession of what is most our own: our own way of flourishing or being fulfilled'. ${ }^{34}$ Parens contrasts a 'gratitude' framework, whereby we view our talents and capacities as gifts, with a 'creativity' framework, which sees us as responsible for using our abilities to 'mend and transform ourselves and the world'. ${ }^{35}$ While we often move between frameworks in different contexts, attending to this 'crude heuristic' and the 'fertile tension' between gratitude and creativity may impart more balance to the overall debate. ${ }^{36} \mathrm{We}$ propose something similar to Parens later in this article but utilise Christian resources to frame it (deification and creaturehood).

Where transhumanists would engineer human flourishing, secular humanists locate this flourishing in an ordinary human life well-lived. If we might speak in terms of creaturehood and deification (though neither group would affirm the theological dimensions of such vocabulary), then secular humanists align with the former in their essentialisation of status quo human nature, while transhumanists gravitate to the deification pole in their vision of radical transformation.

\section{Critical posthumanism}

\footnotetext{
${ }^{32}$ A preliminary comparison of secular humanism and transhumanism with respect to human enhancement is made by Victoria Lorrimar, 'Human Flourishing, Joy, and the Prospect of Radical Life Extension', The Expository Times 129, no. 12 (2018): pp. 554-561.

${ }^{33}$ Erik Parens, 'Authenticity and Ambivalence: Toward Understanding the Enhancement Debate', The Hastings Center Report 35.3 (2005), p. 34.

${ }^{34}$ ibid., p. 35.

35 ibid., p. 37.

${ }^{36}$ ibid., pp. 38, 41.
} 
Transhumanism and secular humanism do not exhaust the range of perspectives on human flourishing in the context of bioenhancement. One other constellation point in the discussion is worth considering for it subscribes neither to the essentialism of secular humanism as endemic to human flourishing nor to the transcendental rupture of present human life required of transhumanism. Instead, critical posthumanism, as it is often referred to, sits somewhere else on the spectrum entirely.

Critical posthumanism differs from the Enlightenment-driven transhumanism we have been discussing here. Represented by figures such as N. Katherine Hayles, Donna Haraway, Cary Wolfe and Rosi Braidotti, critical posthumanism intentionally distances itself from transhumanism precisely because the latter so closely weds itself to the ideals of modernity and Enlightenment humanism. Of course both critical posthumanists and transhumanists agree that the category of the human is fraught with complication, some even arguing we have never been human. ${ }^{37}$ If we have ever been human, both might say, it certainly is not worth protecting. Indeed both agree on precisely the point of leaving the human condition altogether and suggest it is the inherent malleability of the human that leads to such denotative complication. Where they differ is how this malleability is to be treated and understood in human and posthuman life, and also how this relates to their respective visions of flourishing.

We have already attended to transhumanist accounts of flourishing, noting that it is only in exceeding present human life through increased lifespan and cognitive and emotional enhancement that we might finally flourish. The vision transhumanists have for the good life is sought through instrumentalisation of the world around them; they even take this approach towards themselves (both central characteristics of modernity). Because we are malleable we have the opportunity to shape the course of our lives at a fundamental level. The template aimed at, critics of transhumanism note, is embedded in a belief in human exceptionalism, egoism and the solipsistic expansion of the humanistic subject that exemplifies the exacerbation of ideals like autonomy, rationality and liberty. When one alters oneself and one's environment to better suit this vision then we are in a position to flourish.

Critical posthumanism wholeheartedly disagrees with this vision of flourishing and its underlying assumptions about our present condition. Yes, human beings are malleable but it is precisely this malleability that allows us to recognise we are not our own and not the sole shapers of our existences. Whereas certain transhumanists might lament the fact that we aren't solely in charge of our own destiny, critical posthumanists celebrate it and indeed argue we will never flourish if we don't first recognise that our relations with others are endemic to who we are. Hence, critical posthumanists argue for a deep and abiding relationality.

${ }^{37}$ N. Katherine Hayles, How We Became Posthuman: Virtual Bodies in Cybernetics, Literature, and Informatics (Chicago: University of Chicago Press, 1999), p. 291. 
What might make them distinctive is the extent to which other species and entities are implicated in this relationality and the way our formation and identities depend on them. It is not just other human beings that we 'become-with', to use the phrase of Haraway, but other creatures and artefacts, too: 'So if the 'Cyborg Manifesto' is looking at the couplings of cybernetic systems and organisms, the "Companion Species Manifesto" is saying, "Wait a minute, the entity that we are is the outcome of a symbiogenetic doing." We are sympoietic systems; we become-with, relentlessly. There is no becoming, there is only becoming-with. ${ }^{38} \mathrm{We}$ are but the inheritors of an entwined history and actors within a present biological-social-cultural-technological system and, as such, are a being-in-relation.

Now it is difficult to discern precisely what critical posthumanists actually advocate for and what they have in mind regarding human/posthuman flourishing. As one commentator notes: 'This posthumanist ethical-political project is generally underspecified, with speculative appeals to care and flourishing common but still not fully substantiated or worked through. ${ }^{39}$ Is this adherence to deep relationality merely descriptive or is it additionally prescriptive? It is certainly descriptive of our present realities in that without acknowledging our indebtedness to other entities we will never flourish and, furthermore, that we will never flourish unless we are part of a techno-ecology where each member within that relational network also flourishes. This is where Haraway's strongest prescriptive claim enters into the critical posthumanist account of flourishing: 'Make kin, not babies!' 40 The tagline indicates that we take more seriously and actively build extra-filial relations often in replacement of such 'natural', filial bonds. In one way, this is Haraway's attempt to address overpopulation which seriously compromises the flourishing of all entities on earth, but it also extends her account that all entities rely upon one another in a common techno-ecology. ${ }^{41}$

Yet, the question remains whether critical posthumanists also want to make the prescriptive claim to increase greater pluralism in each of the constitutive members. Is there smuggled into their passive acknowledgement of and active support of making kin with present plural bodies and entities an additional imperative to make the most of our malleability and increase the pluralism inherent in the techno-ecology? If there is, critical posthumanists would still be allergic

${ }^{38}$ Donna Haraway and Cary Wolfe, Manifestly Haraway (University of Minnesota Press, 2016), p.221. C.f. Donna Haraway, 'A Cyborg Manifesto: Science, Technology, and Socialist-Feminism in the Late Twentieth Century', in Simians, Cyborgs, and Women: The Reinvention of Nature (New York: Routledge, 1991); Donna Haraway, The Companion Species Manifesto: Dogs, People, and Significant Otherness (Chicago: Prickly Paradigm Press, 2015).

${ }^{39}$ Franklin Ginn, 'Posthumanism', in International Encyclopedia of Geography: People, the Earth, Environment and Technology, ed. D. Richardson et al. (Oxford: Wiley-Blackwell, 2017), p. 5277.

${ }^{40}$ Donna Haraway, 'Anthropocene, Capitalocene, Plantationocene, Chthulucene: Making Kin', Environmental Humanities 6, no. 1 (2015), pp. 161-164.

${ }^{41}$ There is an interesting parallel between Haraway's 'making kin' and the image of adoption as the primary metaphor of our deificatory relation to God. We are gods by grace and adoption rather than by nature and this certainly resonates with Haraway's 'making kin' not as a biological determiner. 
to the jingoism of utopian transhumanists with their fixed gaze on the receding horizon and instead choose to focus on the present entities before us today and the relations with them. It would be less a triumphalistic march of individuals into the adventurous arrow of the future and instead would be more of a cooperative and diverse fellowship that meanders the terrain based upon mutual interest of each member.

\section{Theological perspectives on flourishing and the enhancement debate}

While critical posthumanism ascribes value to our present creaturehood, offering an important critique to the transhumanist emphasis on transcendence, we find similar emphases within contemporary Christian theology. The theological anthropology of Kathryn Tanner, for example, highlights the malleability of human being. Listening to the insights of 'biogenetics', which Tanner interprets as rejecting a 'stable, fixed, and clearly demarcated human nature', she develops an account that foregrounds the plasticity of human nature. ${ }^{42}$

Tanner takes as her starting point the doctrine of the imago Dei. A Christological approach that understands humans to image God only when they are 'radically reworked into the divine image through Christ' requires that human nature is capable of radical transformation i.e. is plastic. ${ }^{43}$ Human worth is located not in human nature per se but in what humans can become: more like God as we 'take in God as [our] proper nourishment'. ${ }^{44}$

The difference between Tanner's position and the critical posthumanist perspective on malleability concerns the telos of human plasticity. Where posthumanists celebrate malleability for its own sake, and for the sake of creaturely difference and pluralism, Tanner speaks of malleability for a purpose. And the purpose she ascribes poses restraints on the type of transformation that human nature might or should undergo: 'It is not just plasticity, then, that is at issue when considering humans as the image of God, but plasticity of a certain sort: openness to, essential dependence upon, the influence of the alien or foreign - God, who is other than creatures, what they are not. ${ }^{45}$

Though Tanner does not engage the biotechnological enhancement debate directly, she issues a challenge to assumptions about human nature premised on inaccurate knowledge of 'biogenetics'. For Tanner, the biological picture is in accord with what we hold to be theologically true also - that human nature must be plastic so that it is capable of being remade after the image of Christ by receiving the Spirit. It is a strong position from which to dialogue

\footnotetext{
${ }^{42}$ Kathryn Tanner, 'Grace without Nature', in Without Nature? A New Condition for Theology, ed. David Albertson and Cabell King (New York: Fordham University Press, 2009), pp. 363-364.

${ }^{43}$ ibid., p. 364.

${ }^{44}$ ibid., p. 365.

${ }^{45}$ ibid., p. 371.
} 
with philosophies advocating for human enhancement, recognising as it does the human capacity for altering the self. McKenny argues, however, that in her emphasis on self-forming and plasticity, Tanner places human worth entirely in what we might become, not what we are now. Ultimately, it is a 'transhumanist theology', denying any value to us as we are in our present creaturehood. ${ }^{46}$

If this critique holds, then Tanner's contribution finds company with a number of other theologians working more specifically in the area of biotechnological enhancement who emphasise the deification pole of human being (either to the neglect or the detriment of creaturehood). Philip Hefner, for example, argues that humans are co-creators with God, and goes as far as to say that transhumanism 'partners' with God in the 'editing and revision' of human being (referring to our biological makeup). ${ }^{47}$ Even the burgeoning Christian Transhumanist Association tends to favour our technological prowess and creative powers often at the expense of affirming our present creaturely goodness. ${ }^{48}$

Other theologians writing on human enhancement have focused instead on the creaturehood pole. Brent Waters, for example, indicates in response to human enhancement advocates that we need to recognise that our limitations are markers of our creaturehood and the basis for us flourishing as human beings. What is more, for him birth and mortality are distinctive features of creaturehood that ought to be maintained in the face of human enhancements that might seek to overcome them. ${ }^{49}$ Celia Deane-Drummond's articles on the topic consistently argue against radical human enhancement projects because their goals often neglect the inherent good in creaturely life and instead seek to represent these distinctive features of creaturehood as problems or limitations to be overcome. The transhumanist attempt to 'reverse engineer' the human mind so as to upload human consciousness into a silicon substrate denies the importance of embodiment to human flourishing and how it is the locus of our connection with other creatures. ${ }^{50}$ Being a creature here means leading an embodied life inseparably related to otherswithout the body there is no relation.

\footnotetext{
${ }^{46}$ McKenny, 'Biotechnology', p. 29.

${ }^{47}$ Philip Hefner, 'The Animal That Aspires to Be an Angel: The Challenge of Transhumanism', Dialog 48, no. 2 (2009), p.161.

${ }^{48}$ See https://www.christiantranshumanism.org/

${ }^{49}$ Brent Waters, 'Whose Salvation? Which Eschatology?: Transhumanism and Christianity as Contending Salvific Religions', in Transhumanism and Transcendence: Christian Hope in an Age of Technological Enhancement, ed. Ronald Cole-Turner (Washington, DC: Georgetown University Press, 2011), pp. 171174; Brent Waters, 'Flesh Made Data: The Posthuman Project in Light of the Incarnation', in Religion and Transhumanism: The Unknown Future of Human Enhancement, ed. Calvin Mercer and Tracy Trothen (Santa Barbara: Praeger, 2015).

${ }^{50}$ Celia Deane-Drummond, 'Taking Leave of the Animal? The Theological and Ethical Implications of Transhuman Projects', in Transhumanism and Transcendence: Christian Hope in an Age of Technological Enhancement, ed. Ronald Cole-Turner (Washington, DC: Georgetown University Press, 2011); Celia Deane-Drummond, 'Remaking Human Nature: Transhumanism, Theology, and
} 
Given the imperative to hold both creaturehood and deification in appropriate tension, an orthodox Christian perspective is unable to uncritically affirm either a transhumanist or secular humanist stance on biotechnological enhancement. Christian theology finds a closer ally in critical posthumanism, with its emphasis on relationality and malleability, yet the lack of a sufficient telos for human being renders posthumanism ultimately inadequate too.

Graham argues that secular naturalist accounts of human nature (which encompass both the transhumanist and secular humanist positions surveyed here) are degraded as a result of the divorce between concepts of God and concepts of humanity and nature. 'To restore a theological horizon is to root these categories in a narrative of divine origin and value, owing their ultimate significance not merely to their own utility or perfectibility but a value that is conferred by an Other who is irreducible to temporal interest or appropriation. ${ }^{51}$ We might extend this critique beyond understandings of human nature itself to the entwined visions of human flourishing bound up in these naturalist accounts. Though critical posthumanism is distinguished from transhumanism and secular humanism by its troubling of what it means to be human, and the challenge it issues to binary definitions and human exceptionalism, it too tends towards naturalism in its reconfiguration of human existence, and lacks the significance of a divine narrative.

How can we bring the critical posthuman strengths on creaturehood together with a more theologically robust understanding of transcendence or telos, restoring the theological horizon called for by Graham? Specifically, is there a place for biotechnological enhancement in achieving transcendence, yet preserving our creaturehood, given that both are fundamental to our flourishing?

A helpful theological anthropology in this space might summarise humans as creatures bound for glory. It preserves the distinction first drawn by Jürgen Moltmann between futurum (the future is a continuation of the present) and adventus (the future arises from outside of time and space as a fulfilment of divine promise), but exchanges history as the object with the human person. ${ }^{52}$ Creatures bound for glory recognises the contributions that technology might make to an improved futurum while acknowledging that adventus is accomplished by divine grace alone. ${ }^{53}$ The affirmation of adventus (i.e. creatures bound for glory) provides the necessary telos that gives meaning to malleability, and a vantage point from which one might legitimately

Creatureliness in Bioethical Controversies', in Religion and Transhumanism: The Unknown Future of Human Enhancement, ed. Calvin Mercer and Tracy Trothen (Santa Barbara: Praeger, 2015).

${ }^{51}$ Graham, 'Bioethics after Posthumanism', p. 194.

${ }^{52}$ Jürgen Moltmann, The Coming of God: Christian Eschatology, trans. Margaret Kohl (Minneapolis, MN: Fortress Press, 1996), pp. 25-6.

${ }^{53}$ Michael Burdett treats the classification of transhumanist visions of the future as futurum extensively in Eschatology and the Technological Future (New York: Routledge, 2015). 
protect certain creaturely limits, so sought after by secular humanists. ${ }^{54}$ And the understanding that bound for glory is describing an adventus future, rather than futurum, shifts the final responsibility of engineering such a future away from us, as transhumanists would have it, assigning God and grace as the proper agent of the future glory we anticipate. Biotechnological enhancements take their fitting place; they are neither categorically prohibited nor imperative. Like other applications of technology, they become the subject of ongoing ethical deliberation.

It is worth clarifying here that we regard God and human action on the development of the human being as complementary and in no way competitive. For, all that is human, everything it is and is to be, is bestowed by a loving Creator who also redeems and glorifies. To see 'creatures' as the correlate of self-contained and whole 'nature', apart from reference to God as source and aim, is to miss a defining feature of being a creature: dependency on God. In this way, humanity qua creature is already graced and that being deified by divine grace neither compromises its creatureliness or undermines its integrity. ${ }^{55}$ Rather, God's grace both brings the human creature to its creaturely glory and at the same time adopts this creature to divine fellowship to participate in the divine life. Tanner captures this polarity well in her understanding that humans enjoy a 'natural connection' with God as a result of the incarnation, indeed, the malleability she emphasises is imparted by grace and prepares us to receive further grace. ${ }^{56}$

This notion of creatures bound for glory is thus productive for engaging the other positions discussed here, and offers helpful language to distinguish their respective emphases on either the creaturehood or deificatory dimensions of human existence. Transhumanists hope to be gods, not creatures, and secular humanists and posthumanists both affirm different versions of already glorious creatures. Transhumanists require the overcoming of creaturely finitude to properly experience human flourishing, yet such finitude is crucial for flourishing from the secular humanist perspective. Critical posthumanists defend neither finitude nor its defeat, but focus instead on the dissolving of boundaries between non-human and human as the fruit of creaturely malleability. In espousing creatures bound for glory, however, a Christian theological perspective enables humans both to flourish in the here and now, yet acknowledge that we are not all that we should or could be, and therefore place our hope in eschatological redemption. Our proposal indicates that our creatureliness and our deification do not stand at odds with one

\footnotetext{
${ }^{54}$ In their elevation of the 'natural', without recourse to an external good that imparts worth, secular humanists have a difficult time justifying what precisely is natural and why that makes it necessarily good.

${ }^{55}$ Henri de Lubac's comments on the natural and supernatural ends of humanity are integral to this understanding. See Henri de Lubac, Surnaturel: études historiques (Paris: Aubier, 1946).

${ }^{56}$ This interpretation is somewhat at odds with McKenny's assessment of Tanner's position as 'transhumanist theology', rather Tanner accords worth to humans not simply because of what they might become, but because they are already gifted with the openness necessary for transformation. Tanner locates any inability to flourish in our present stage in our sinfulness, not in our created nature, which has the capacity to receive God and thus be transformed. See Kathryn Tanner, Christ the Key (Cambridge University Press, 2009), pp. 69-77.
} 
another, as is often represented in theological discussions of human enhancement, but are instead a part of one grand vision God has for humanity. 